サルの血管系のためのレントゲン解剖技法について*

\author{
小 原 二 郎
}

(横浜市野毛山動物 園)

横地千伋・岩井 博

(横浜市立大学医学部)

吉 村 将 文
(横 浜 山 手 病 院)

\section{はじめに}

動物体の立体的構造を正確に把握することは，従来の 解剖法によるのみでは往ヶ不充分を免れない。それを補 らべく種々な技法があるが，レントゲン写真の応用は極 めて有利なものである。すでに MESCHAN ら4) および NISHIWAKI ら ${ }^{5)}$ は種々な解剖学的研究にこれを忘用し ている。岩井ら ${ }^{2)} は$ 臨床レ線像の基礎研究の一部として ではあるが，人屍体の血管系に造影剤を注入して撮 影 し，さらにその涷䊅薄切の断面に現れる血管系をも撮影 した。FALLAR 1) はヒトにおいて，宮川『は家音におい て体諸部の血管系を同様に研究している。

われわれは，近時実験動物としてしばしば利用される サルにつんて，全身血管柔を立体的に把握し，さらに， 従来の技法では解析不充分な拡大鏡的微小構造までる観 察しらるレントゲン解剖技法を研究した。

\section{材料}

1. 動物：主としてかにくいざる(Macaca irus)。瓜 かに，に瓜んざる (Macaca fuscata)，てながざる(Hylobates sp), チンパンヂー(Anthropithecus niger) をも もちいた。てれらの個体はなるべく成熟したものを選ぶ ほか，外見，レ線透視，レ線撮影後の肉眼解剖などによ って，著明な渏形，病変などを認めないものを採用し た。これらの多くは死体で入手された。

2. 造影剂：市販のリュウバリゾルにゼラチンを少量 添加したものと，ゼラチンの 5〜10\% 温水溶液で 3〜5 倍に稀釈したものをもちらた。ゼラチンは注入された造 影剤の流動性を失わせるために加える。をたレ線吸収の 度合を平均化するためには，注入のはじめに濃厚液を入 れ，後に稀勫液を入れれば,細小血管には濃厚な状態で, 大血管には稀薄な状態で入り，造影効果は平均化され る。とのほかレ線撮影後の肉眼解剖時に, 白色の本品は 注入された血管を追究するのに指標となりらる。

3. 装置と感光材料 : 装置は臨床用固定式, 同ポータ ブル式 (共に常用電圧)，およびソフテックス(低電圧)

\footnotetext{
* 本論要旨は既に第 49 回日本獣医学会において発表し 同時に写真も供覧した。
}

をもちんた。感光材料は医療用ならびに工業用レントゲ ンフィルム，およびリスフィルムなどをもちんた。

\section{方法}

1. 前処置：a．生体を用々る場合：深麻酔をほどと し，人パリンを体重 $\mathrm{kg}$ 当 $0.5 \mathrm{mg}$ 静脈内に注入する。 次に大腿動脈を外科的に引を出儿，それぞれ求心性にカ ニューレを插入結着し，遠位端を結禁，静脈より加温生 理的食塩水を徐々に注入し，一方注入量とほほ同等量に 調節しつつ動脈より放血し, 必要に応じ麻酔剤あるいは ヘパリンを追加しつつ死に至らしめ，死後ただちに造影 剂を注入する。

b . 死体を用いる場合：死体で入手した材料には次の 処置と注意が必要である。新鮮な死体では血管の緊張が あり，血管内に凝血がある。をた死強により体形の変更 が困難で，ただちに材料としてもちらるには適しない。 とのよ5な場合,死体を約 $5^{\circ} \mathrm{G}$ K冷葴し，㢁敗を抑制し つつカタラーゼによる血液の溶解と死強の緩解をまつ。 これには 48〜72 時間を要する。死体の脈管は破損しや すく, 臓器の位置変化も起りやすんので, 処置の間に死 体の移動運搬はできるだけ避け，取扱いはとくに慎重を 要する。

2. 造影剂注入：注入は生体を処理した材料の場合に は放血にもちんたカニューレをそのまま，死体材料の場 合は生体の放血時におとなった処置同様に大腿動脈を出 してカニューレを結び，注射筒をもちん，必ずレントゲ ン透視下で注入の状況を観察しつつ，できらる限り低王 で徐々に注入しなければならない。また末稍部へ充分に 注入するには，その部を低く保つか，それら各部の主幹 動脈にそいマッサージをおこならか，一応の注入が終っ た後にそれらの主幹動脈にカニューレを装着し追加注入 を㧊となえばよい。注入量は体重の $1 / 27 〜 1 / 30$ 量が限 界のよらである。

3. 撮影：a. 全身撮影：要領は臨床のそれと同様で あるが，体幹などの撮影においては，灌流による体液の 増加と造影剤による散乱線の増加のため必ずブッキーを 要する。しかし対象物が静止の状態にあるので，像の拡 大や半影ボケを避け鮮明な像をらるため充分な距離をと 
Table 1. 1st Expo: Technique

\begin{tabular}{c|c|c|c|c|c|c|c|c|c}
\hline Case & Thickness & Bucky & Intensifying screen & Films & Dist. & K.V.P. & mA & Sec. & Contents \\
\hline \hline Head & $8 \mathrm{~cm}$ & yes & F, S. & $\begin{array}{c}\text { Medic ; } \\
\text { X-R.ay } \\
\text { Film }\end{array}$ & $2 \mathrm{~m}$ & 45 & 5 & 8 & $\begin{array}{c}\text { Philips } \\
\text { DX-3 }\end{array}$ \\
\hline Stem & $12 \mathrm{~cm}$ & yes & F, S. & 50 & 5 & 8 & \\
\hline Limb & $2.5 \mathrm{~cm}$ & no & F, S. & & 45 & 5 & 6 \\
\hline Limb periphery & $1 \mathrm{~cm}$ & no & no & & 45 & 5 & 6 \\
\hline
\end{tabular}

Table 2. 2nd, 3rd Expo.: Technique

\begin{tabular}{|c|c|c|c|c|c|c|c|c|c|}
\hline Case & Thickness & Bucky & Intensifying screen & Films & Dist. & K.V.P. & $\mathrm{mA}$ & Sec. & Contents \\
\hline Block & $5 \mathrm{~cm}$ & no & F, S. & Medic; X-Ray Film & $1 \mathrm{~m}$ & 45 & 70 & 0.1 & $\begin{array}{c}\text { Philips } \\
\text { DX-3 }\end{array}$ \\
\hline Slices & $3 \mathrm{~mm}$ & no & $\mathrm{F}, \mathrm{S}$. & Listype Film & $25 \mathrm{~cm}$ & 15 & 3 & 360 & $\begin{array}{c}\text { Softex } \\
\text { B }\end{array}$ \\
\hline
\end{tabular}

り, 低電圧, 弱電流とし, 露出時間の延長により充分な線 量を与えればよい。さらにノンスクリーン撮影や，厚さ の異る部分については普通写真の引伸しにおける覆焼同 様の露出調整撮影も可能である。かくしてえられた写真 の解析のため立体撮影が必要であるがその手技は成書に ゆずる。全身撮影の条件 1 例仕表 1 亿示す通りである。

b. 摘出臟器䄧よびその薄切片の撮影：造影剤は注入 後数時間経過すればその水分が脈管から組織内に漏出 し，添加したゼラチンによって流動性を失い，切断面よ り溢出しなくなる。そとで各臟器を取り出し，ホルマリ ン液で充分固定し，撮影の材料とする。撮影法は全身の 場合と同じであり，ての場合にも解析のため立体撮影を 行らべをである。次に実質臓器などにつき，さらに部分 的な拡大鏡的追究を行らため資料をゼチラン包埋によっ て薄切し用いる。薄切片の厚さは連続切片が採取できる 限り薄いものが望ましい。この撮影には臨床用装置もも ちんられるが，細部を明確に表現するとはソフテッックス とリスフィルムの組合せによれば明細な像がえられる。 てれらの撮影条件の 1 例は表 2 亿示す通りである。

\section{考察}

造影剂は臨床飞常用される油性あるいは，水溶性のも のもあるが，それらは解剖研究の目的には注入後流動性 を失わず，あるいは組織内へ漏出したりして不適当なの で，固体粒子造影剤として毎回均一な状態で入手しやす レリュウバリゾルを選んだ。撮影にあたって対象が動か ずまた放射線障害も問題外であるので，長時間露出や 超長波レ線を使用し得，さらにノンスクリーン和よび微 粒子フィルムの組合せにより鮮明な血管像がえられた。 立体撮影も完全な効果がえられる。とてに述べた方法に よりえられた血管造影立体写真によれば，全身血管の走 行を容易に立体的に把握するととができ，さらに各個臟
器の血管の立体的走行と拡大鏡的追究も容易にできる。

\section{むす び}

サルの全身血管系の立体的把握と拡大鏡的追究にレン トゲン写真の応用は極めて有利であり，次の要領でおて なえばよい。

1. 生体を利用する場合は麻酔を施し， ヘパリンをも ちい，静脈内一生理的食塩水注入を和てないつつ動脈よ り放血し，死に至らしめて使用し，死体の場合は死後約 $5^{\circ} \mathrm{C}$ K 48〜72 時間保存したものをもちんる。

2. 造影剤は固体粒子の懸濁液をもちん，主として大 腿動脈よりレントゲン透視下で徐々飞注入する。

3. 体幹など形は小さくとも造影剂などにより散乱線 が増すから，撮影にはブッキーを必要とする。

4. 全景撮影後は摘出臟器個々の撮影をし, 必要に応 じノンスクリーン撮影を応用する。

5. 摘出臓器はさらに薄切し撮影する。乙の場合超長 波レントゲン線と，微粒子フィルムの組合せでおとなえ ば拡大鏡的追究ができる。

6. これらの撮影は対象が動かないから，像の鮮明化 のため充分な距離をとり，なるべく低電圧，弱電流で時 間をかけて和てない，すべて立体撮影飞より解析する。

\section{文献}

1) FALLER, A. (1957): Das Verhalten der Arteriellen Gefässe in den verschiedenen Wandschichten des Rectum beim Menschen. Act. Anat., 30, 275 286.

2) 岩井 博 外 (1959): エックス線解剖学 I. 日医放 誌, 19, 1679 1687.

3) 岩井 博 外 (1960): エックス線解剖学 II. III. 第 117 回日医放学会関東部会 (口頭報告)。

4) MESChAN, I. (1954): An atlas of normal radio- 
graphic anatomy. W. B. Saunders. Philadelphia.

5) NISIWAKI M., et al. (1959): Mesoplodon stejnegeri from the coast of Japan. Scien. Rep. Whal. Inst., No. 14, 35 48.

6) S.ANTE, L. R. (1942) : Manual of roentgenological technique. Edwards Brothers. Ann Arbor, Michgan.
7）宮川 正 (1957)：犬の四肢に分布する動脈のレ線 立体解剖学的研究。日獣 誌, 19-附録 (学会号), 104 105。

8) 吉村将文 外 (1960)：屍体材料（人体及動物）の造 影撮影に関する研究。第 16 回日放技会総会(口頭報 告)。

\title{
A New Roentgenological Method for the Study of Cardiovascular System of Monkey
}

\author{
Jiro KOBARA \\ (Nogeyama Zoological Garden, Yokohama) \\ Chihiro YococHI \\ (Anat. Dept., Med. Faculty, Yokohama Univ.) \\ Hiroshi IWAI \\ (Rad. Dept., Med. Faculty, Yokohama Univ.) \\ Masafumi Yoshimura \\ (Yamate Hospital, Yokohama)
}

The roentgenological techniques for the giography of monkey were described. The techniques were proved to be useful either for stereotypic analysis of the cardiovascular system or in a magnificating studies with the organ slice following the administration of the contrast media.

A live monkey should be examined by arteriopuncture under the intravenous anesthesia with pentbarbitulate. In the case of dead monkey, it was recommended to leave the body in $5^{\circ} \mathrm{C}$ for 48 to 72 hrs. before the application of contrast media.

The emulsified contrast media was introduced slowly into the femoral artery under a fluoroscopy.

Bucky was necessary for the better results in the roentgenography of a whole body or the trunk.

No screen expose technique was used for the better result to the individual organs.

In order to obtain a sharp picture, an enough distance for focal spot, low voltage and waek current were recommended since the exposure has not any limitation for the still object. 


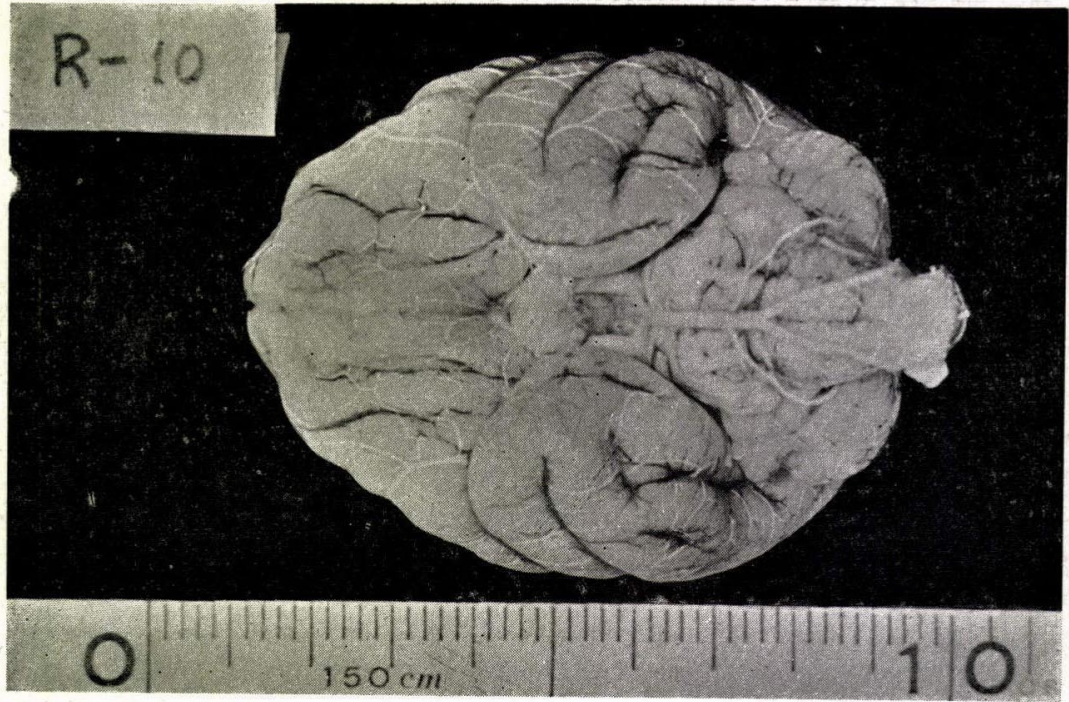

Photo 1. Brain removed after injection of contrast media. Note main artery filled with media in white color distinctively.

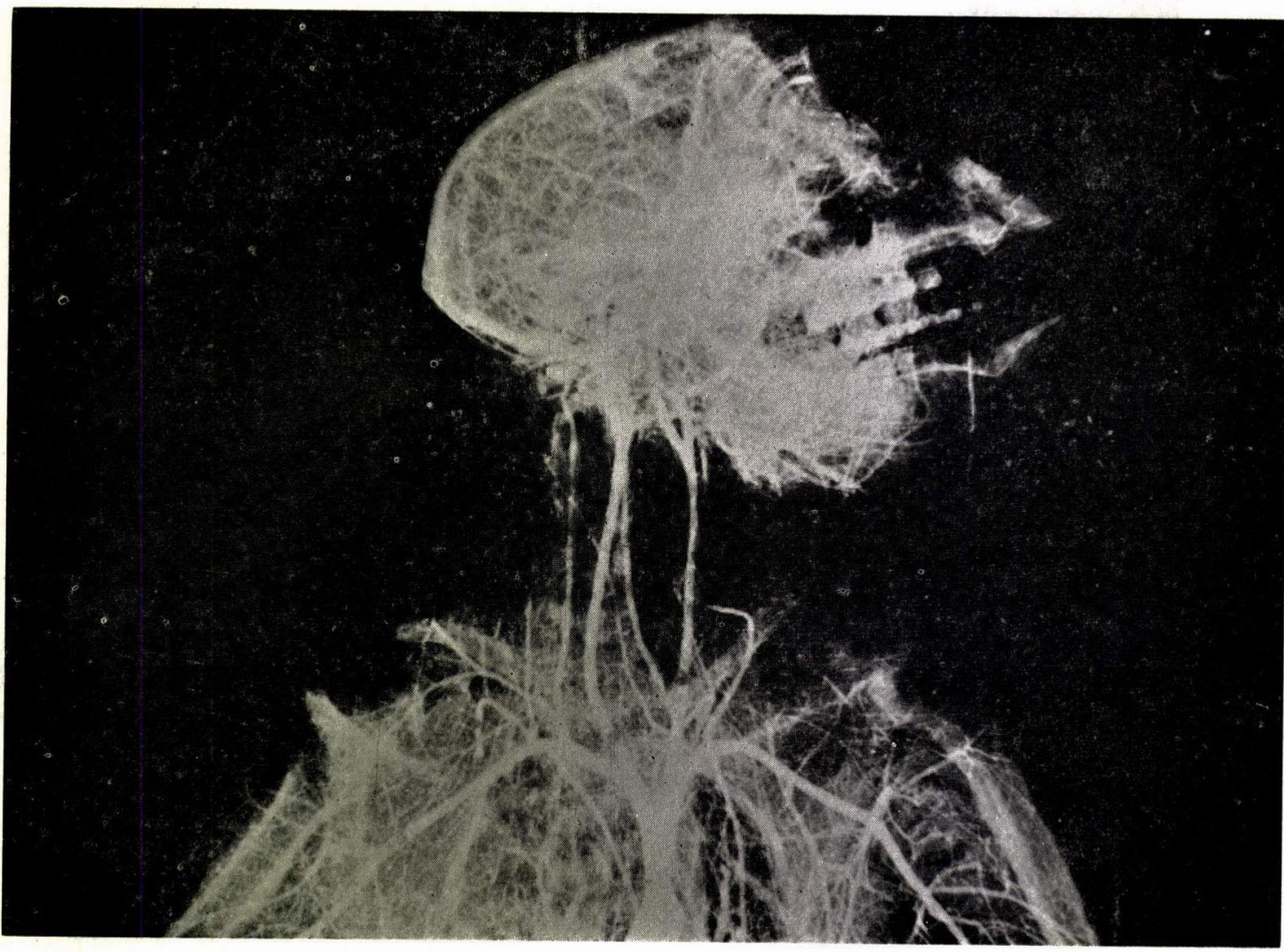

Photo:2. Arterial distribution of head and neck. 


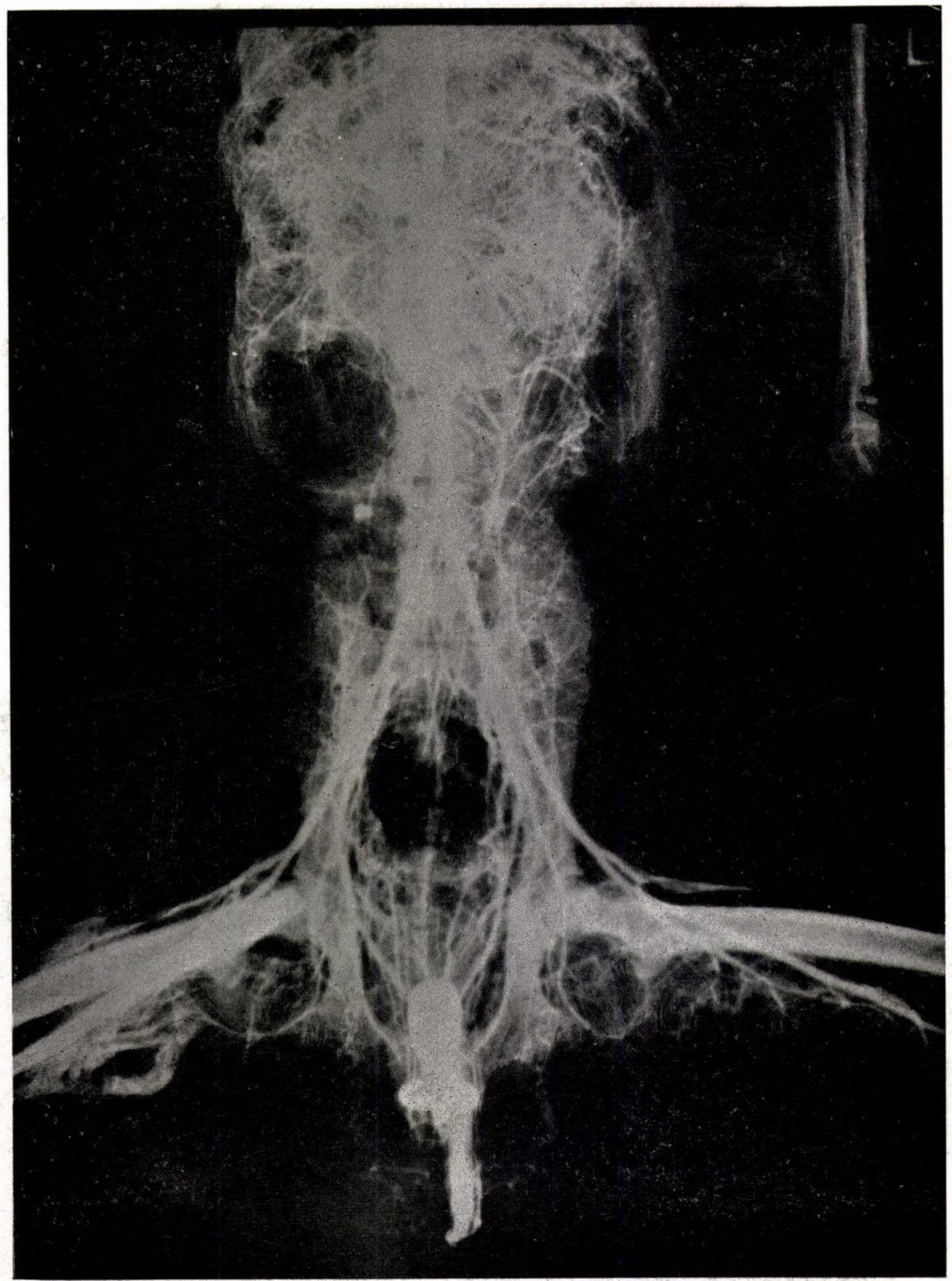

Photo 3. Arterial distribution of the abdomen and pelvis. 


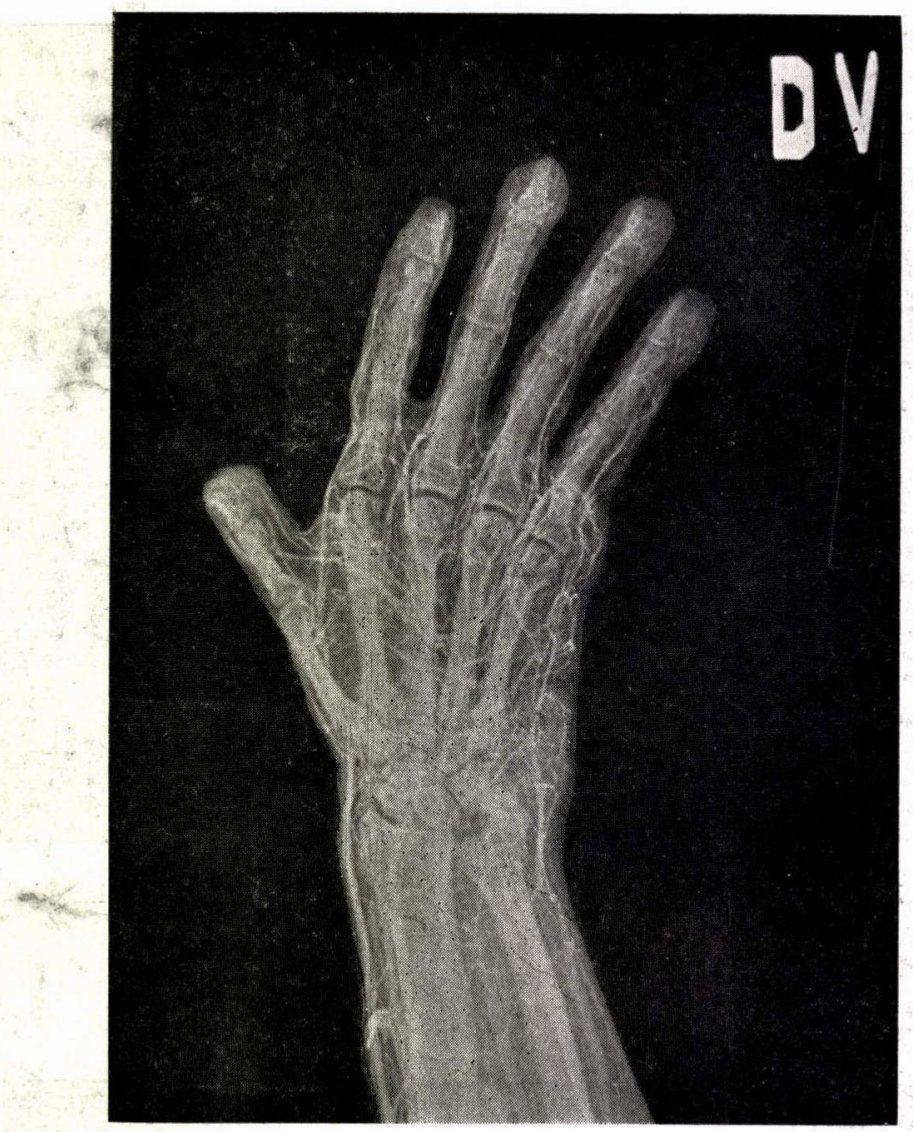

Photo 4. Arterial distribution of the forearm and hand.

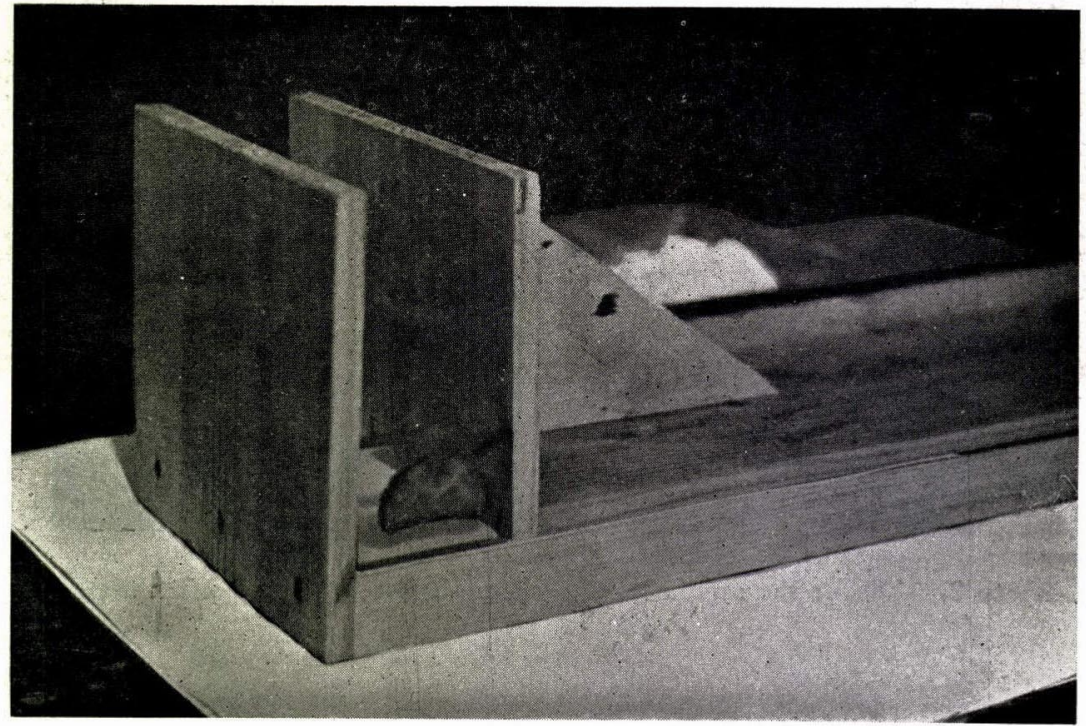

Photo 5. Hand cutter for brain block $3 \mathrm{~mm}$ thick. 

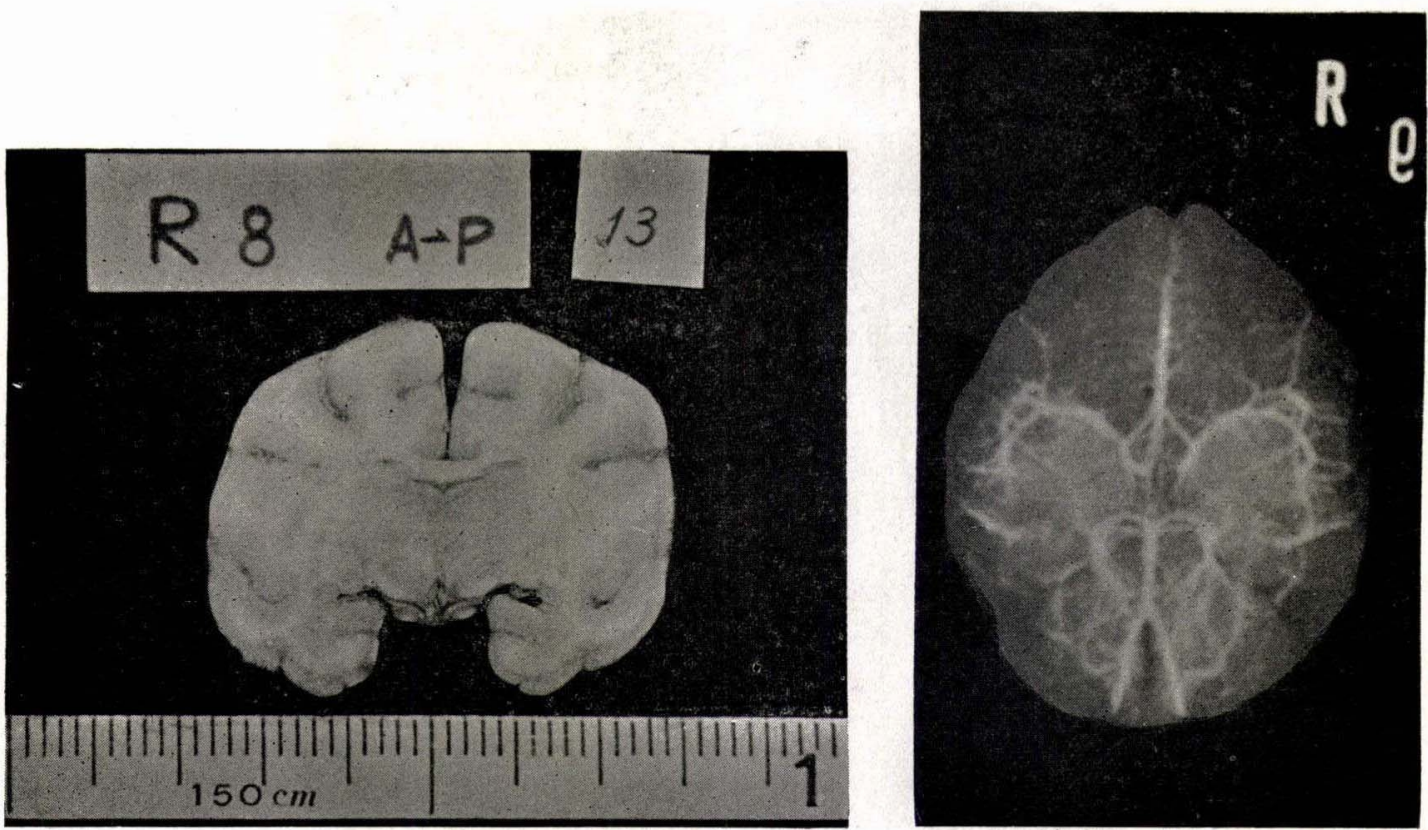

Photo 6. The 13th slice from the very front.

Photo 7. X-ray film of the brain artery.

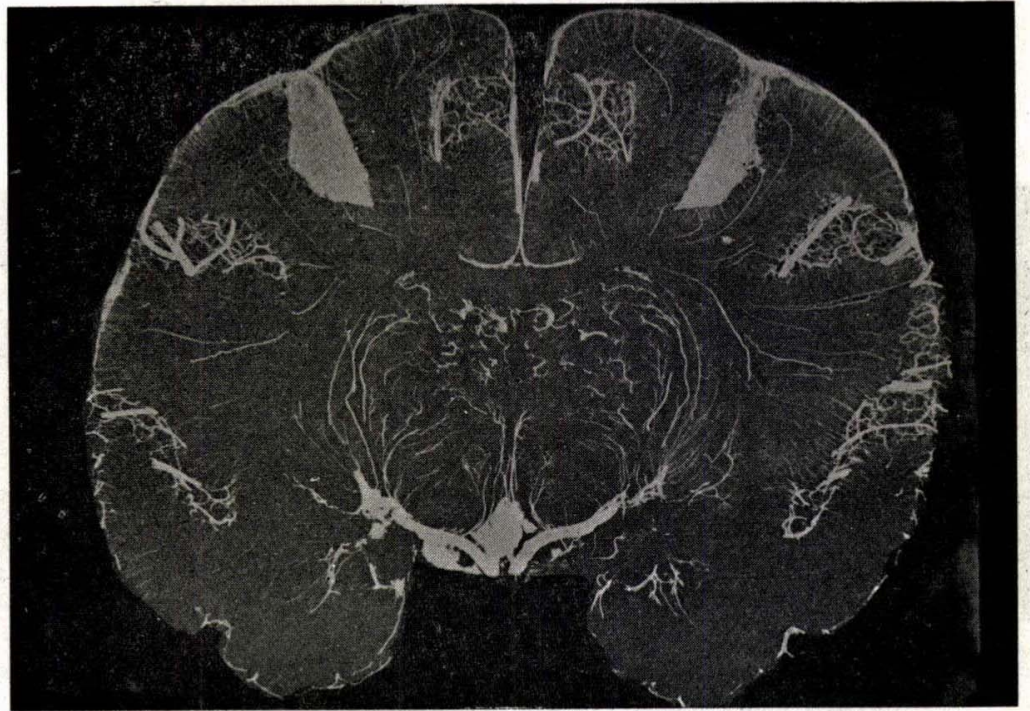

Photo 8. Shows the capillaries of a slice (photo 6) taken by softex film. 